\title{
MULTIDYSCYPLINARNA KONFERENCJA NAUKOWA W POZNANIU „OD ARCHEOLOGII JÓZEFA KOSTRZEWSKIEGO DO WSPÓŁCZESNYCH NAUK O PRZESZLOŚCI SPOŁECZNEJ". PRZEGLĄD PORUSZONEJ PROBLEMATYKI
}

W dniach 21 i 22 września 2017 r. odbyła się w Poznaniu ogólnopolska konferencja naukowa pt. „Od archeologii Józefa Kostrzewskiego do współczesnych nauk o przeszłości społecznej”. Konferencję, w imieniu Poznańskiego Towarzystwa Przyjaciół Nauk (dalej jako PTPN), które w bieżącym roku obchodzi jubileusz 160-lecia istnienia, zorganizowali prof. Tomasz Jurek (Instytut Historii PAN) oraz prof. Michał Kara (Instytut Archeologii i Etnologii PAN), we współpracy z dr Jarmilą Kaczmarek, dr. Pawłem Dembińskim i Piotrem Wawrzyniakiem. Organizatorzy reprezentowali Wydział Historii i Nauk Społecznych PTPN i/lub Komisję Archeologiczną PTPN. Patronat nad konferencją przyjęli: Prezes PTPN prof. Andrzej Gulczyński, Prezydent Miasta Poznania Jacek Jaśkowiak oraz Rektorzy: Uniwersytetu im. Adama Mickiewicza w Poznaniu - prof. Andrzej Lesicki, Uniwersytetu Medycznego w Poznaniu - prof. Andrzej Tykarski, Uniwersytetu Przyrodniczego w Poznaniu - prof. Jan Pikul, i Politechniki Poznańskiej - prof. Tomasz Łodygowski.

Konferencja zainicjowała zorganizowany przez PTPN - w związku z wymienionym wyżej jubileuszem - cykl spotkań naukowych pt. „Człowiek a dziedzictwo”, poświęcony wybitnym uczonym ośrodka poznańskiego. Uznano, iż każdemu z sympozjów powinna towarzyszyć dyskusja nad znaczeniem myśli wspomnianych badaczy oraz ich dorobku dla rozwoju nauki, nie tylko polskiej, jak również nad współczesnymi możliwościami poznawczymi dziedzin wiedzy, które reprezentowali. Nawiązując do ideowego przesłania Poznańskiego Towarzystwa Przyjaciół Nauk, przyjęto, iż formuła planowanych spotkań naukowych nie powinna ograniczać kręgu odbiorców.

Wybór konferencji poświęconej dziedzictwu naukowemu Profesora Józefa Kostrzewskiego (1885-1969), jako inaugurującej cykl sympozjów „Człowiek a dziedzictwo", nie był przypadkowy. Uhonorowano w ten sposób jednego z głównych twórców nowoczesnej archeologii polskiej, jednocześnie naukowca niezwykle zasłużonego dla Poznańskiego Towarzystwa Przyjaciół Nauk oraz utworzonego 


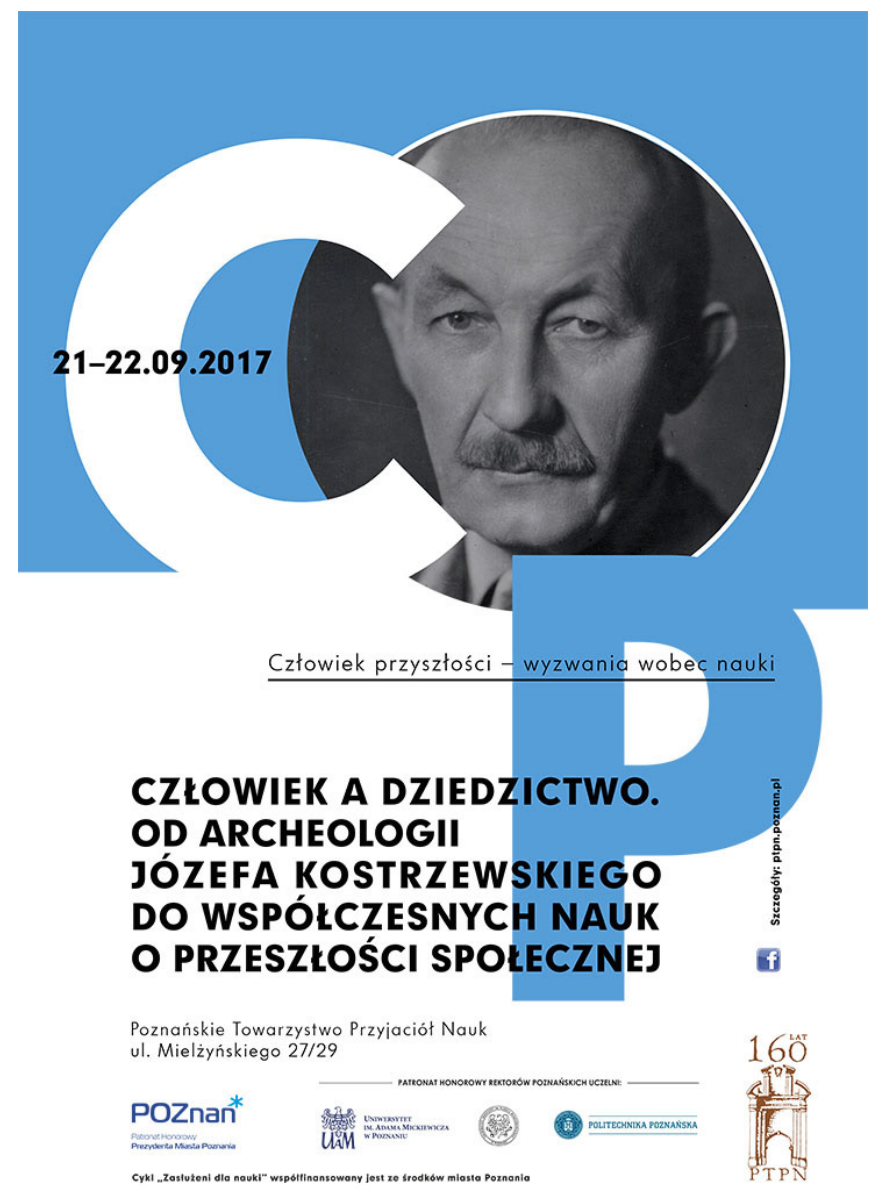

Plakat z informacją o konferencji. Z archiwum PTPN

w 1919 r. Uniwersytetu Poznańskiego, jego współtwórcy i profesora, a także założyciela i dyrektora Muzeum Archeologicznego w Poznaniu, które do 1939 r. funkcjonowało w budynku PTPN. Nie ulega wątpliwości, że dorobek oraz dzieło tego wybitnego archeologa, a zarazem wielkiego Człowieka i patrioty, badacza reliktów grodu ludności kultury łużyckiej w Biskupinie (obok Faras w północnym Sudanie to najbardziej znane na świecie odkrycie polskiej archeologii), już w okresie przedwojennym zdeklarowanego rzecznika współpracy prehistorii (obecnie prahistorii) z innymi dyscyplinami naukowymi, którego poglądy do dziś wzbudzają ożywione dyskusje, zasługują na ponowną refleksję. Realizowana przez Józefa Kostrzewskiego koncepcja badań zintegrowanych wpisuje się bowiem, jak rzadko która, w założenia problemowe wspomnianego cyklu sympozjów organizowanych w związku z jubileuszem PTPN. 
Za główny cel konferencji przyjęto zatem prezentację współczesnych metod odtwarzania różnych nurtów zmaterializowanych przejawów przeszłości społeczno-kulturowej, które realizowane są w ośrodkach naukowych Polski, m.in. w poznańskim, w ramach zintegrowanych, multidyscyplinarnych badań archeologicznych bądź badań prowadzonych we współpracy z archeologią. Uznano, iż najlepszym sposobem realizacji wspomnianych celów będzie prezentacja na określonych przykładach wybranych zagadnień, które finalnie poddane zostaną wielostronnej dyskusji z udziałem nie tylko przedstawicieli nauk historycznych, przede wszystkim archeologii, lecz również nauk społecznych, ścisłych, przyrodniczych, geograficznych oraz medycznych. Obecność wspomnianych nauk obserwujemy bowiem w modelu prehistorii integralnej, skutecznie realizowanym od lat trzydziestych XX w. w poznańskiej szkole archeologicznej Józefa Kostrzewskiego.

W programie konferencji znalazło się 17 referatów (zob. aneks); jeden nie został wygłoszony z przyczyn losowych (dr Aneta Bukowska, ,Zintegrowane badania wczesnej architektury Piastów. Cele, potencjał i praktyka z perspektywy historyka architektury"). Wystąpienia zostały uporządkowane w trzy grupy problemowe: 1) wokół modelu i uwarunkowań metodyczno-metodologicznych multidyscyplinarnych badań archeologicznych, ze szczególnym uwzględnieniem badań osadniczych; 2) wokół relacji archeologii, jako nauki, do innych dyscyplin, zwłaszcza historiografii; 3) wokół nowych metod przydatnych w badaniach archeologicznych.

Konferencję rozpoczął referat dr. Andrzeja Prinke. Dokonano w nim szczegółowej charakterystyki modelu studiów archeologicznych, jaki realizowany był w zespole Józefa Kostrzewskiego zgodnie z obowiązującym wówczas paradygmatem nauki pozytywistycznej, twórczo adaptowanym przez Profesora na potrzeby jego studiów archeologicznych (prehistorycznych). Ów model działań naukowo-badawczych wyróżniał wzmiankowany powyżej, rozbudowany nurt analiz multidyscyplinarnych, które były zlecane i moderowane przez archeologów. Istotne znaczenie w praktyce badawczej wspomnianego zespołu odgrywały dwie zasady: pierwsza, dotycząca dbałości o publikację sukcesywnie pozyskiwanych źródeł archeologicznych, oraz druga, kładąca nacisk na popularyzację w szerokich kręgach społecznych najnowszych wyników prac wykopaliskowych. Dodajmy, iż obie zasady, konsekwentnie przestrzegane w tzw. archeologicznej szkole Józefa Kostrzewskiego i stanowiące jej swoisty znak firmowy, obecnie nie należą do praktyk powszechnie obowiązujących w archeologii polskiej, z ewidentną szkodą dla tej ostatniej.

Należy podkreślić, że wygłoszony na wstępie konferencji referat Andrzeja Prinke miał kluczowe znaczenie dla przebiegu spotkania, w zasadniczym zarysie prezentował bowiem zespół zagadnień, które znalazły odzwierciedlenie w kolejnych referatach, oczywiście w odniesieniu do obecnego stanu wiedzy.

I tak, pierwszego dnia konferencji, podczas sesji przedpołudniowej scharakteryzowano współczesny, zintegrowany model wieloaspektowych badań multi- lub interdyscyplinarnych, realizowany w studiach nad przeszłością społeczną, w którym 


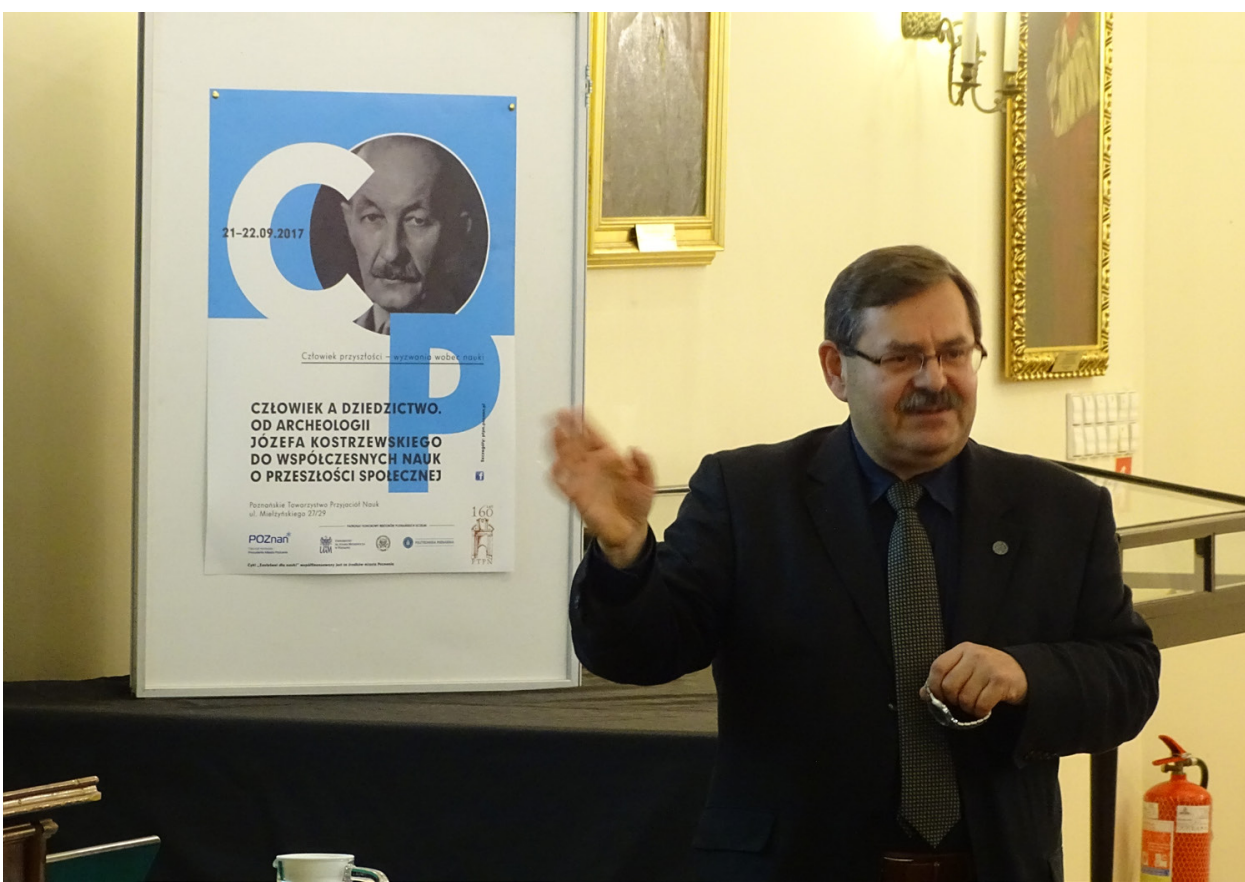

Ryc. 2. Profesor Marek Krąpiec z AGH w Krakowie podczas wygłaszania referatu. Z archiwum PTPN. Fot. A. Gulczyński

korzysta się nie tylko z analiz biologów, geografów, geologów czy etnografów (co praktykował już Józef Kostrzewski), lecz czerpie się również z doświadczeń wyspecjalizowanego rzemiosła, np. ludwisarstwa. Możliwości i ograniczenia poznawcze wspomnianego modelu badań przedstawił na przykładzie wybranych średniowiecznych mikroregionów osadniczych z obszaru Wielkopolski prof. Andrzej Marek Wyrwa.

Udziałowi metod nieinwazyjnych (fotografia lotnicza, badania geofizyczne) w archeologicznych studiach nad osadnictwem pradziejowym, średniowiecznym i nowożytnym, które obecnie pod wpływem doświadczeń geografii oraz geoekologii coraz częściej postrzega się jako studia nad zintegrowanym krajobrazem przyrodniczo-kulturowym, poświęcone było kolejne wystąpienie w ramach wymienionej wyżej sesji, przygotowane przez dr. Grzegorza Kiarszysa. W referacie podkreślono znaczenie interpretacji archeologicznych (opartych na rzetelnej wiedzy specjalistycznej) dla ustaleń wykorzystujących dane, które uzyskuje się za pomocą wspomnianych metod.

Podobne uwagi zawarto w dwu kolejnych referatach. Pierwszy, traktujący o zagadnieniach archeoprzyrodniczych, wygłosiła dr Iwona Okuniewska-Nowaczyk, natomiast drugi, poświęcony archeozoologii - prof. Daniel Makowiecki. W obu przypadkach problematykę badań bioarcheologicznych przybliżono na konkretnych 
przykładach z pradziejów lub średniowiecza ziem polskich, przy czym w przypadku zagadnień z zakresu archeozoologii omówiono też możliwości poznawcze wdrażanych dopiero analiz molekularnych. Te ostatnie przydatne są w ustaleniu diety, a także kierunku migracji historycznych wspólnot ludzkich, którym towarzyszą zwierzęta hodowlane (na tej podstawie rysuje się szczególna rola wspomnianych analiz dla studiów nad procesem tzw. neolityzacji obszaru Europy). W obu wystąpieniach sporo uwagi poświęcono współpracy archeologów z przedstawicielami nauk biologicznych, owocnej zwłaszcza w szeroko rozumianych studiach osadniczych archeologii. Model wspomnianej współpracy uległ od czasów badań Józefa Kostrzewskiego istotnej transformacji ideowej. W tym kontekście wskazuje się na autonomię archeologii oraz nauk biologicznych w zakresie formułowania prawomocnych, nierzadko alternatywnych wniosków w ramach współczesnego modelu zintegrowanych studiów historycznych, co w modelu multidyscyplinarnych badań osadniczych Józefa Kostrzewskiego nie zawsze było zasadą. W tym przypadku preferowano bowiem archeologię jako dyscyplinę wiodącą dla rekonstrukcji przemian historyczno-kulturowo-osadniczych, podczas gdy informacje uzyskiwane od przedstawicieli dyscyplin tzw. towarzyszących traktowano jako cenne uzupełnienie analitycznych dociekań prehistorii (archeologii). Referenci podkreślili jednak, iż w nowoczesnym modelu badań bioarcheologicznych rola archeologii w ustaleniach z zakresu periodyzacji, chronologii, funkcji oraz atrybucji społecznej i kulturowej badanych źródeł kopalnych jest niepodważalna.

Zbliżony zespół zagadnień problemowych został poruszony podczas obrad popołudniowych. Wygłoszone tu cztery referaty - przez profesorów Leszka Pawła Słupeckiego, Mariana Rębkowskiego, Dariusza Główkę i dr hab. Annę Zalewską - pozwoliły podjąć dyskusję nad aktualnym stanem relacji archeologii z historiografią. Jakkolwiek nie wypracowano w tej kwestii ujednoliconego stanowiska (dla części archeologów oraz historyków archeologia to jedynie metoda badawcza prahistorii lub antropologii przeszłości, z czym trudno się do końca zgodzić), to jednak uczestnicy konferencji jednomyślnie zaprzeczyli tezie, stosunkowo powszechnej w czasach Józefa Kostrzewskiego, aczkolwiek nierzadko podzielanej też obecnie, jakoby archeologia (prahistoria) stanowiła w systemie nauk historycznych dyscyplinę pomocniczą historiografii. Osiągnięcia badawcze archeologii, notowane nie tylko dla pradziejów, starożytności, średniowiecza, ale również dla młodszych stadiów okresu nowożytnego (o badaniach $\mathrm{z}$ tego odcinka czasu traktował m.in. referat dr hab. Anny Zalewskiej), nie pozostawiają wątpliwości co do autonomicznego charakteru archeologii jako dyscypliny naukowej, aktualnie chyba bardziej społeczno-historycznej niż historycznej. Interpretuje ona pozyskiwane przez siebie źródła kopalne na podstawie własnego warsztatu badawczego (przyswajanego podczas studiów uniwersyteckich), który pozwala odtwarzać przeszłość głównie w zakresie społecznym i kulturowym, a w koincydencji ze źródłami pisanymi, źródłami lingwistyki historycznej oraz danymi antropologii fizycznej także w zakresie kulturowo-etnicznym, zawsze jednak w ramach słabiej lub silniej uargumentowanych 
hipotez naukowych, które w sposób świadomy lub bezrefleksyjny archeolodzy budują w zgodzie z przesłankami określonego paradygmatu naukowego. Należy podkreślić, że odtwarzana metodami archeologii przeszłość kulturowa i społeczna nigdy nie jest równoznaczna $\mathrm{z}$ rekonstrukcją kompletną rzeczywistości badanego odcinka dziejów, ze względu na przypadkowy oraz „niemy” charakter źródeł archeologicznych tudzież ich fragmentaryczność. Wspomniana okoliczność decyduje też o hipotetycznym wymiarze ustaleń archeologii, przy czym poziom ufności formułowanych przez archeologię (prahistorię) wniosków wzrasta w miarę przyrostu informacji źródeł pisanych o badanym odcinku dziejów.

W omawianych referatach, zwłaszcza w wystąpieniu Anny Zalewskiej, dotyczącym problematyki badań pól bitewnych z okresu Wielkiej Wojny na obszarze Polski Środkowej, podkreślono też społeczny wymiar rezultatów badawczych współczesnej archeologii. Przejawia się on m.in. w odnotowywanym coraz częściej w Polsce zjawisku aktywizacji zainteresowania historią lokalną przez miejscowe wspólnoty. Według Anny Zalewskiej badania archeologiczne prowadzone na polach bitewnych, zwłaszcza z okresu wielkich wojen światowych, przyczyniły się do uwrażliwienia miejscowych społeczności na okrucieństwo wojny, ukazując ich głęboko niehumanitarny charakter, który dotknął żołnierzy różnych nacji uczestniczących po obu stronach konfliktu. Opisane zjawisko badaczka uznaje za dowód żywotności archeologii jako nauki humanistycznej, otwartej na nowe nurty kultury społecznej. Nawiązując do poglądów Anny Zalewskiej, warto postawić pytanie, czy archeolodzy stymulują wspomniane nurty, czy może tylko aktywnie dostosowują się do nich?

Drugi, a zarazem ostatni dzień konferencji poświęcony był prezentacji wybranych metod lub specjalizacji badawczych, z których wyników korzysta się w nowszych studiach archeologii. Posługując się konkretnymi przykładami, scharakteryzowano: 1) możliwości datowań radiowęglowych oraz wskazań dendrochronologicznych w ustaleniach archeologii z zakresu chronologizacji oraz periodyzacji znalezisk (prof. Marek Krąpiec); 2) metodę eksperymentalnego wypału naczyń przydatną w badaniach archeologicznych nad przemianami technologii produkcji ceramiki naczyniowej z obszaru Wielkopolski w okresie przedrzymskim (dr Milena Teska, prof. Andrzej Michałowski, Marta Krzyżanowska); 3) możliwości poznawcze petroarcheologii w badaniach kultury i gospodarki społeczeństw pradziejowych i średniowiecznych ziem polskich (dr Ewa Lisowska); 4) przydatność izotopowych analiz związków ołowiu w badaniach nad proweniencją kruszcu srebrnego użytkowanego na ziemiach polskich we wczesnym średniowieczu (Dariusz Wyczółkowski, prof. Władysław Duczko, dr Adam Kędzierski); 5) możliwości współczesnych metod identyfikacji, obrazowania i wizualizacji w kontekście interdyscyplinarnych badań ludzkich szczątków kostnych z materiałów archeologicznych (dr Dorota Lorkiewicz-Muszyńska i in.).

Wymienione wystąpienia poprzedził referat Piotra Wawrzyniaka, który na przykładzie Poznania omówił wybrane aspekty współczesnych badań archeologicznych średniowiecznego i wczesnonowożytnego miasta lokacyjnego. Ponieważ we wspo- 
mnianych badaniach korzysta się z wyników opisanych powyżej metod oraz specjalizacji badawczych, referat ów stanowił dobre wprowadzenie do problematyki kolejnych prezentacji.

Ostatnie, kończące jednocześnie konferencję, było wystąpienie Mateusza Sikory i Agnieszki Stempin, którzy przedstawili nowoczesne formy ekspozycji znalezisk archeologicznych bądź stosowane w Rezerwacie Archeologicznym Genius loci na Ostrowie Tumskim w Poznaniu, bądź planowane w związku z realizacją na wspomnianym Ostrowie skansenu archeologicznego z czasów pierwszych władców piastowskich. Warto podkreślić, iż w rezerwacie Genius loci zwiedzający mogą zapoznać się $\mathrm{z}$ bardzo nowoczesną i unikatową w formie (nie tylko w Polsce) prezentacją reliktów fortyfikacji grodu Mieszka I i Bolesława Chrobrego. Odkrycie wspomnianego grodu nastąpiło tuż przed wybuchem II wojny światowej przez ekspedycję archeologiczną ówczesnego Uniwersytetu Poznańskiego pod ogólnym kierunkiem Józefa Kostrzewskiego. Dodajmy: już wtedy z inicjatywy prof. Kostrzewskiego przygotowano wstępne plany budowy obiektu muzealnego, w którym zamierzano udostępnić szerokiej publiczności odsłonięte pozostałości grodu. Referat Mateusza Sikory i Agnieszki Stempin stanowił zatem istotne dopełnienie wystąpienia dr. Andrzeja Prinke z samego początku konferencji, w którym przedstawione zostały m.in. poglądy Józefa Kostrzewskiego na sposoby uspołeczniania odkryć archeologicznych.

Referatom towarzyszyła ożywiona dyskusja merytoryczna. Próby podsumowania dwudniowych obrad podjęła się prof. Hanna Kóčka-Krenz. W krótkim wystąpieniu m.in. stwierdziła, iż naukowcy badający obecnie przeszłość społeczną nawiązują zarówno pod względem ideowym, jak i merytorycznym do zapoczątkowanego w latach trzydziestych XX w. przez Profesora Józefa Kostrzewskiego modelu multidyscyplinarnych studiów archeologicznych. Ten ostatni został twórczo rozwinięty w okresie powojennym (zwłaszcza w dwu ostatnich dekadach), co nie zmienia faktu, iż współcześni badacze stoją na ramionach prawdziwego giganta i wizjonera nauki, jakim dla nowoczesnej archeologii polskiej jest Józef Kostrzewski. Według Hanny Kóčki-Krenz przytoczona metafora celnie oddaje ideowe przesłanie debaty poznańskiej.

Organizatorzy konferencji zobowiązali się do jak najszybszej publikacji referatów (także niewygłoszonych). Podkreślili, zgodnie z opinią uczestników debaty, iż niezależnie od zarysowania potencjalnych możliwości poznawczych współczesnej archeologii polskiej, przedstawione referaty pozwoliły również ponowić dyskusję nad ustaleniem właściwych relacji badawczych archeologii z innymi dyscyplinami nauk, przede wszystkim z historiografią. Istotną okolicznością był udział w debacie młodszego pokolenia archeologów, których poglądy pozwalają zorientować się w kierunkach nowych interpretacji badanej przeszłości oraz w nowych możliwościach ekspozycji znalezisk archeologicznych w obiektach muzealnych. 


\section{ANEKS}

\section{Program ogólnopolskiej konferencji naukowej}

\section{„Od archeologii Józefa Kostrzewskiego do wspólczesnych nauk o przeszłości społecznej”.} Poznańskie Towarzystwo Przyjaciól Nauk, 21-22 września 2017 r.

\section{Czwartek, 21 września 2017 r.}

Otwarcie konferencji: Prezes PTPN prof. Andrzej Gulczyński (9.00-9.15)

Sesja przedpołudniowa

dr Andrzej Prinke (9.15-9.45)

Archiwum PAN w Warszawie,

Oddział w Poznaniu

Józefa Kostrzewskiego prehistoria integralna: badania terenowe z szerokim kontekstem przyrodniczym - publikacje źródłowe - popularyzacja wyników

prof. Andrzej Marek Wyrwa (9.45-10.15)

Instytut Historii UAM

w Poznaniu

O możliwościach $i$ potrzebie wieloaspektowych badań interdyscyplinarnych $w$ poznaniu przeszłości w świetle badań tekneńskiego kompleksu osadniczego i Ostrowa Lednickiego

dr Aneta Bukowska (10.15-10.45)

Instytut Historii Sztuki UJ

w Krakowie

Zintegrowane badania wczesnej architektury Piastów. Cele, potencjat i praktyka z perspektywy historyka architektury

Dyskusja (10.45-11.15)

Przerwa na kawę (11.15-11.30)

dr Grzegorz Kiarszys (11.30-12.00)

Katedra Archeologii

Uniwersytetu Szczecińskiego

Od studiów osadniczych do archeologii krajobrazu. Nieinwazyjne metody badawcze w interpretacjach archeologicznych

dr Iwona Okuniewska-Nowaczyk (12.00-12.30)

Instytut Archeologii i Etnologii PAN w Poznaniu

Rola badań archeoprzyrodniczych - wczoraj $i$ dziś

prof. Daniel Makowiecki (12.30-13.00)

Instytut Archeologii UMK w Toruniu

Studia nad przeszłościa społeczna i przyrodnicza $w$ archeozoologii makroskopowej oraz molekularnej

Dyskusja (13.00-13.30) 
Obiad 13.30-15.30

Czwartek, 21 września 2017 r.

Sesja popołudniowa

prof. Leszek Pawel Słupecki (15.30-16.00)

Instytut Historii Uniwersytetu w Rzeszowie

Jak zrozumieć naszych przodków z X wieku? Wybrane problemy badań interdyscyplinarnych nad początkami Polski (i nie tylko Polski) od czasów Józefa Kostrzewskiego do chwili obecnej

prof. Marian Rębkowski (16.00-16.30)

Instytut Archeologii i Etnologii PAN w Szczecinie

O znaczeniu archeologii $w$ badaniach czasów historycznych

prof. Dariusz Glówka (16.30-17.00)

Instytut Archeologii i Etnologii PAN w Warszawie

Historia kultury materialnej a archeologia

dr hab. Anna Zalewska (17.00-17.30)

Instytut Archeologii UMCS w Lublinie;

Instytut Archeologii i Etnologii PAN w Warszawie

$Z$ otchtani wieku... Refleksja nad rola społeczna $i$ znaczeniem poznawczym archeologii czasów wspótczesnych

Dyskusja (17.30-18.00)

Piątek, 22 września 2017 r.

mgr Piotr Wawrzyniak (9.00-9.30)

Pracownia Archeologiczno-Konserwatorska „mgr Alina Jaszewska” w Zielonej Górze,

Oddział w Poznaniu

O niektórych aspektach badań archeologicznych $w$ mieście. Uwagi praktyka

prof. Marek Krąpiec (9.30-10.00)

Katedra Stratygrafii i Geologii Regionalnej AGH w Krakowie

Datowania bezwzględne $w$ archeologii (dendrochronologia $i$ analiza radioweglowa) aktualne możliwości i ograniczenia

Przerwa na kawę (10.00-10.15)

dr Milena Teska, prof. Andrzej Michałowski, mgr Marta Krzyżanowska (10.15-10.45) Instytut Archeologii UAM w Poznaniu Archeometria - klucz do poznania ceramiki zabytkowej 
dr Ewa Lisowska (10.45-11.15)

Instytut Archeologii Uniwersytetu Wrocławskiego

Petroarcheologia w badaniach nad gospodarka spoleczeństw pradziejowych i średniowiecznych

Dyskusja (11.15-11.45)

Przerwa na kawę (11.45-12.00)

mgr Dariusz Wyczółkowski, prof. Władysław Duczko, dr Adam Kędzierski (12.00-12.30)

Instytut Archeologii i Etnologii PAN w Warszawie

Badania fizykochemiczne o pochodzeniu i obiegu srebra w Polsce wczesnopiastowskiej

dr Dorota Lorkiewicz-Muszyńska, dr Michał Rychlik, dr Wojciech Kociemba, dr Mariusz Glapiński, dr Tomasz Kulczyk (12.30-12.45)

Katedra i Zakład Medycyny Sądowej

Uniwersytetu Medycznego im. Karola Marcinkowskiego w Poznaniu

Wspótczesne metody identyfikacji, obrazowania $i$ wizualizacji $w$ interdyscyplinarnych badaniach ludzkich szczątków kostnych z materiałów archeologicznych

mgr Mateusz Sikora, mgr Agnieszka Stempin (12.45-13.00)

Muzeum Archeologiczne w Poznaniu

Rezerwat Archeologiczny Genius loci w Poznaniu

Popularyzacja archeologii - nowe spojrzenie na przykładzie Rezerwatu Archeologicznego

Genius loci $w$ Poznaniu

Dyskusja (13.00-13.30)

Podsumowanie i zamknięcie obrad:

prof. Hanna Kóčka-Krenz (Instytut Archeologii UAM w Poznaniu) 